\title{
Feeding ratio and frequency affects cadmium bioaccumulation in black sea bream Acanthopagrus schlegeli
}

\author{
Zhiqiang Guo', Wei Zhang ${ }^{1}$, Yanyan Zhou ${ }^{1,2}$, Na Gao, ${ }^{1,2}$, Li Zhang ${ }^{1, *}$ \\ ${ }^{1}$ Key Laboratory of Tropical Marine Bio-resources and Ecology, Guangdong Provincial Key Laboratory of Applied Marine Biology, \\ South China Sea Institute of Oceanology, Chinese Academy of Sciences, Guangzhou 510301, PR China \\ ${ }^{2}$ University of the Chinese Academy of Sciences, Beijing 100049, PR China
}

\begin{abstract}
Feeding ratio and frequency have substantial effects on food digestion and assimilation in fish, yet few attempts have been made to determine their influences on the bioaccumulation of trace metals. In this study, juvenile Acanthopagrus schlegeli were exposed to either waterborne or dietary cadmium $(\mathrm{Cd})$ at different feeding ratios $\left(0,2\right.$, or $4 \%$ body weight $\mathrm{d}^{-1}\left[\mathrm{BW} \mathrm{d} \mathrm{d}^{-1}\right]$ under waterborne $\mathrm{Cd}$ exposure and $1,2.5$, or $4 \% \mathrm{BW} \mathrm{d}^{-1}$ under dietary $\mathrm{Cd}$ exposure) or feeding frequencies $\left(1,2\right.$ or 8 times $\left.\mathrm{d}^{-1}\right)$ for $5 \mathrm{wk}$. Under waterborne $\mathrm{Cd}$ exposure, the fish fed $0 \% \mathrm{BW} \mathrm{d}^{-1}$ or 8 times $\mathrm{d}^{-1}$ showed significantly lower growth rates and those fed $0 \% \mathrm{BW} \mathrm{d}^{-1}$ or 1 time $\mathrm{d}^{-1}$ exhibited higher $\mathrm{Cd}$ body burdens and $\mathrm{Cd}$ uptake rates compared to the other groups. The gut showed a significantly higher waterborne Cd uptake rate than the gills when fish were fasted or fed only 1 time $d^{-1}$. These results suggest that starvation and low feeding frequency facilitate waterborne Cd uptake. Under dietary Cd exposure, the fish fed $4 \% \mathrm{BW} \mathrm{d}^{-1}$ or 2 times $\mathrm{d}^{-1}$ grew faster. Cd body burden and Cd assimilation were higher in fish fed $2.5 \% \mathrm{BW} \mathrm{d}^{-1}$ or 2 times d $\mathrm{d}^{-1}$. Dietary Cd retention was positively correlated with feed efficiency, suggesting the utilization of Cd probably coincides with the essential nutrients in fish. Overall, this study demonstrates that different feeding strategies significantly influence waterborne and dietary Cd bioaccumulation in marine fish. Therefore, feeding conditions have to be considered carefully for managing trace metal contamination in marine fish farming.
\end{abstract}

KEY WORDS: Feeding strategy $\cdot$ Trace metals $\cdot$ Metal uptake $\cdot$ Metal assimilation $\cdot$ Marine fish

\section{INTRODUCTION}

Globally, 128 million tons of fish provided about 3 billion people with almost $20 \%$ of their average per capita intake of high-quality animal protein in 2010 (FAO 2012). However, the wide spread of trace metal pollution in agricultural and urban soils (Wei \& Yang 2010, Luo et al. 2012) and estuarine and coastal regions (Pan \& Wang 2012) has resulted in an increasing risk of trace metal contamination in aquaculture environments (e.g. sediments and seawater; Pan \& Wang 2012), as well as in fish feed ingredients (Mai et al. 2006, Dang \& Wang 2009, Wei \& Yang 2010), and thus the high risk of excessive trace metal con-

${ }^{*}$ Corresponding author: zhangli@scsio.ac.cn tents in aquatic products. For example, several investigations have found high $\mathrm{Cd}$ contents in aquatic foods and the high risk of $\mathrm{Cd}$ exposure to humans by aquatic food consumption in coastal areas ( $\mathrm{Yu}$ et al. 2006, Wu et al. 2013). Previous studies have largely focused on how physico-chemical environmental factors affect $\mathrm{Cd}$ bioaccumulation in aquatic organisms. Yet few attempts have been made to determine the effects of realistic management practices on Cd bioaccumulation in fish. Feeding ratio and frequency, for instance, are critical for production costs and water quality in intensive fish farming. Earlier studies have indicated that feeding ratio and frequency have significant effects on the nitrogen and energy budget

(C) The authors 2015. Open Access under Creative Commons by Attribution Licence. Use, distribution and reproduction are unrestricted. Authors and original publication must be credited. 
(Sun et al. 2003), growth rate and body composition of black sea bream (Acanthopagrus schlegeli; Lou et al. 2006, 2007), whereas it is unclear how these parameters influence trace metal bioaccumulation in farmed fish in trace metal-contaminated environments.

Aquatic animals accumulate trace metals from both dietary and dissolved phases. Diet is the predominant route of exposure for most aquatic organisms (Rainbow 2007, Wang et al. 2012). Several studies have demonstrated that dietary trace metal assimilation is closely related to the ingestion rate (IR) and gut passage time (GPT) of diets (Zhang \& Wang 2006a, Croteau et al. 2007). Feeding ratio and frequency have a substantial influence on the IR and GPT of diets in fish (Lee et al. 2000, Riche et al. 2004), and thus probably affect the assimilation process of dietary trace metals. Although a growing body of study has revealed that changes in food quality have a significant effect on dietary metal assimilation in farmed marine fish (e.g. food type [Wang \& Wong 2003, Zhang \& Wang 2006a] and dietary protein sources [Mai et al. 2006, Wang et al. 2012]), little is known about the influence of food quantity management (e.g. feeding ratio and frequency adjustments) on dietary metal bioaccumulation in farmed fish.

In addition, feeding patterns may also impact waterborne metal uptake in fish (Hashemi et al. 2008, Wood et al. 2010). Since most marine fish drink seawater continuously to maintain osmotic homeostasis (Grosell 2006) and intestines are the major sites for the uptake of dissolved metals (Zhang \& Wang 2007a), feeding and digestion can alter the waterdrinking rate (Wood et al. 2010) and physico-chemical environment of fish intestines (e.g. pH and acid-base levels [Taylor et al. 2007, Bucking et al. 2009] and major ion concentrations [Bucking et al. 2011]). For instance, Wood et al. (2010) found that gulf toadfish Opsanus beta under daily satiation feeding accumulated much less waterborne Ag in whole body, liver and white muscle samples than those without feeding. To the best of our knowledge, however, there is a surprising paucity of available literature addressing the impacts of realistic feeding management actions on waterborne heavy metal uptake in marine fish.

Black sea bream Acanthopagrus schlegeli is a popular and valuable commercial fish in East Asia (e.g. China, Japan, Korea and some other countries of Southeast Asia) due, for example, to its high growth rate, good meat quality, excellent adaptability to environments and resistance to diseases (Gonzalez et al. 2008, Zhang et al. 2012). Earlier studies indicated that feeding ratio and frequency have significant effects on the nitrogen and energy budget (Sun et al.
2003) and the growth rate and body biochemical composition of black sea bream in uncontaminated environments (Lou et al. 2006, 2007). With respect to $\mathrm{Cd}$ bioaccumulation in black sea bream, our previous studies demonstrated that the gastrointestinal tract is the main site for dissolved Cd uptake (Zhang \& Wang 2007a) and dissolved Cd bioaccumulation is apparently affected by metal pre-exposure (Zhang \& Wang 2005, 2006b), water salinities (Zhang \& Wang 2007b) and body size (Zhang \& Wang 2007c). Nevertheless, it remains unclear how feeding ratio and frequency influence growth and $\mathrm{Cd}$ bioaccumulation in black sea bream. In the present study, we therefore conducted a $5 \mathrm{wk}$ feeding experiment to examine the effects of feeding ratio and frequency on (1) growth performance and feed utilization, (2) Cd body burden and (3) waterborne Cd uptake and dietary Cd assimilation efficiency in juvenile black sea bream.

\section{MATERIALS AND METHODS}

\section{Experimental fish and culture conditions}

Juvenile black sea bream was purchased from South China Sea Fisheries Research Institute (artificial reproduction). The initial Cd content of fish was $0.2 \pm$ $0.03 \mu \mathrm{g} \mathrm{g}^{-1}$ dry weight (mean $\pm \mathrm{SD}$ ). Before the feeding experiment, all fish were fed with extruded diet (Fujian Tianma Science \& Technology; the proximate composition is shown in Table 1 ; the Cd content was

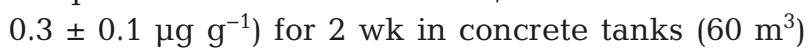
with aerated natural seawater ( 32 to $34 \mathrm{psu}$ ). Then, the fish were starved for $24 \mathrm{~h}$, and 25 fish with uniform body size (initial body weight, $24.5 \pm 0.3 \mathrm{~g} \mathrm{fish}^{-1}$ ) were randomly transferred to $120 \mathrm{l}$ aquaria for the feeding experiment. During the feeding experiment,

Table 1. Proximate composition and cadmium $(\mathrm{Cd})$ contents of experimental diets (in dry matter). Values are means $\pm \mathrm{SD}$ $(\mathrm{n}=4)$

\begin{tabular}{|lcc|}
\hline Composition & $\begin{array}{c}\text { Diets without } \\
\text { Cd addition }\end{array}$ & $\begin{array}{c}\text { Diets with } \\
\text { Cd addition }\end{array}$ \\
\hline Dry matter (\%) & $93.8 \pm 3.2$ & $95.7 \pm 2.6$ \\
Crude protein (\%) & $36.1 \pm 0.2$ & $36.5 \pm 0.26$ \\
Crude lipid (\%) & $4.6 \pm 0.1$ & $4.2 \pm 0.36$ \\
Ash $(\%)$ & $8.2 \pm 0.1$ & $8.2 \pm 0.26$ \\
$\mathrm{Na}^{+}\left(\mu \mathrm{g} \mathrm{g}^{-1}\right)$ & $3.1 \pm 0.5$ & $1.8 \pm 0.4$ \\
$\mathrm{~K}^{+}\left(\mu \mathrm{g} \mathrm{g}^{-1}\right)$ & $20.5 \pm 1.4$ & $15.6 \pm 2.9$ \\
$\mathrm{Ca}^{2+}\left(\mu \mathrm{g} \mathrm{g}^{-1}\right)$ & $9.6 \pm 1.0$ & $8.9 \pm 0.6$ \\
$\mathrm{Mg}^{2+}\left(\mu \mathrm{g} \mathrm{g}^{-1}\right)$ & $5.7 \pm 0.5$ & $4.2 \pm 0.9$ \\
${\mathrm{Cd}\left(\mu \mathrm{g} \mathrm{g}^{-1}\right)}^{0.3 \pm 0.1}$ & $254.4 \pm 11.0$ \\
\hline
\end{tabular}


the natural seawater was aerated to maintain dissolved oxygen at $>6.5 \mathrm{mg} \mathrm{l}^{-1}$, water temperature ranged from 25 to $28^{\circ} \mathrm{C}$ and ammonia-N was $<23 \mu \mathrm{mol}$ $1^{-1}$. The feeding experiment was subjected to natural photoperiod (July to August 2013). The concentration of $\mathrm{Cd}$ in natural seawater was $1.2 \pm 0.2 \mu \mathrm{g} \mathrm{l^{-1 }}$.

\section{Cd exposure and feeding ratio and frequency}

In the present study, there were 4 series of experiments to test the effects of feeding ratio and feeding frequency on waterborne and dietary exposure separately (Table 2). There were 2 control groups of 25 fish fed 2 times $\mathrm{d}^{-1}$ at $3 \%$ body weight $\mathrm{d}^{-1}\left(\mathrm{BW} \mathrm{d}^{-1}\right)$ without Cd exposure. The control groups were mainly used to monitor the aquaculture system and to provide background values for $\mathrm{Cd}$ concentrations in fish under the present experimental conditions (Table 2).

Series 1: waterborne Cd exposure-effect of feeding ratio

In waterborne $\mathrm{Cd}$ exposure experiments, the waterborne Cd concentration was $100 \mathrm{\mu g} \mathrm{l}^{-1}$ (the measured value was $97.2 \pm 2.5 \mu \mathrm{gl}^{-1}$ as $\mathrm{CdCl}_{2}, 99.5 \%$; Guangzhou Chemical Reagent Factory). Three levels of feed- ing ratios $\left(0,2\right.$ and $\left.4 \% \mathrm{BW} \mathrm{d}^{-1}\right)$ were chosen to test the effects of feeding ratios on fish growth and waterborne $\mathrm{Cd}$ bioaccumulation (the feeding frequency was at a normal level, i.e. 2 times $\mathrm{d}^{-1}$; Table 2).

\section{Series 2: waterborne Cd exposure-effect of feeding frequency}

To test the effect of feeding frequency on fish growth and $\mathrm{Cd}$ bioaccumulation in waterborne $\mathrm{Cd}$ exposure experiments, 3 levels of feeding frequency were selected (1 [at 9:00 h], 2 [at 9:00 and 15:00 h]

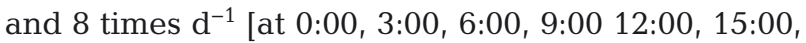
18:00 and 21:00 h]). The feeding ratio was at a normal level, i.e. $3 \% \mathrm{BW} \mathrm{d}^{-1}$.

\section{Series 3: dietary Cd exposure-effect of feeding ratio}

In dietary $\mathrm{Cd}$ exposure experiments, the dietary $\mathrm{Cd}$ concentration was $250 \mathrm{\mu g} \mathrm{g}^{-1}$ (the measured value was $254.4 \pm 11.0 \mu^{-1} \mathrm{~g} \mathrm{~g}^{-1}$ ). To add $\mathrm{Cd}$ to the extruded diet, the diet was spiked with $\mathrm{CdCl}_{2}$ solution (90 $\mathrm{mg}$ $\mathrm{l}^{-1}, 1: 3 \mathrm{in} \mathrm{g} \mathrm{ml}^{-1}$ ) for $1 \mathrm{~h}$ and then dried for $48 \mathrm{~h}$ at $60^{\circ} \mathrm{C}$. Three levels of feeding ratios $(1,2.5$ and $4 \%$ $\mathrm{BW} \mathrm{d}^{-1}$ ) were chosen to test the effects of feeding

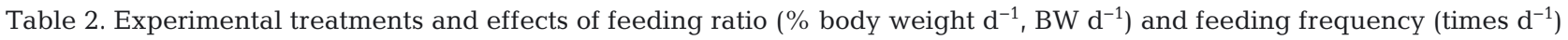
on growth performance, feed utilization and body composition of black sea bream Acanthopagrus schlegeli exposed to waterborne $\left(97.2 \mu \mathrm{g} \mathrm{l}^{-1}\right)$ or dietary cadmium $\left(254.4 \mathrm{\mu g} \mathrm{g}^{-1}\right)$ for $5 \mathrm{wk}$. Values are means $\pm \mathrm{SD}_{\text {; }}$ means in bold with different superscripts were significantly different between the treatments $(\mathrm{p}<0.05)$; means in normal print were not significantly different. FR $\left(\% B W \mathrm{~d}^{-1}\right)$ : feeding ratio (measured values in brackets); FF (times $\left.\mathrm{d}^{-1}\right)$ : feeding frequency; $\mathrm{FBW}\left(\mathrm{g}\right.$ fish $\left.{ }^{-1}\right)$ : final body weight; SGR (\% $\left.\mathrm{d}^{-1}\right)$ : specific growth rate; FE (\%): feed efficiency; DM (\%): dry matter; CP (\%, in dry matter): crude protein; CL $(\%$, in dry matter): crude lipid. Values are means of replicated groups in FBW, SGR, and FE. Values are means of 6 individuals from replicated tanks in DM, CP, CL and ash

\begin{tabular}{|c|c|c|c|c|c|c|c|c|}
\hline \multicolumn{2}{|c|}{ Experimental treatment } & \multirow[b]{2}{*}{ FBW } & \multirow[b]{2}{*}{ SGR } & \multirow[b]{2}{*}{ FE } & \multirow{2}{*}{$\begin{array}{l}\text { utilization } \\
\text { DM }\end{array}$} & \multirow{2}{*}{$\begin{array}{l}\text { nd body con } \\
\mathrm{CP}\end{array}$} & \multirow{2}{*}{\multicolumn{2}{|c|}{ Ash }} \\
\hline FR & FF & & & & & & & \\
\hline \multicolumn{9}{|c|}{ Series 1: waterborne exposure - FR } \\
\hline 0 & 2 & $24.2 \pm 0.7^{a}$ & $-0.16 \pm 0.04^{\mathrm{a}}$ & - & $27.3 \pm 1.5$ & $53.8 \pm 2.5$ & $8.2 \pm 3.5^{\mathrm{a}}$ & $34.5 \pm 3.0^{\mathrm{a}}$ \\
\hline $2(1.95 \pm 0.12)$ & 2 & $37.9 \pm 0.6^{b}$ & $1.15 \pm 0.02^{b}$ & $16.9 \pm 0.8^{\mathrm{a}}$ & $31.9 \pm 2.2$ & $53.6 \pm 3.6$ & $20.2 \pm 4.3^{\mathrm{b}}$ & $22.1 \pm 1.8^{b}$ \\
\hline $4(3.81 \pm 0.04)$ & 2 & $40.1 \pm 1.6^{b}$ & $1.35 \pm 0.08^{\mathrm{c}}$ & $10.7 \pm 0.6^{b}$ & $30.9 \pm 0.6$ & $53.9 \pm 2.0$ & $23.2 \pm 3.9^{b}$ & $19.3 \pm 2.5^{b}$ \\
\hline \multicolumn{9}{|c|}{ Series 2: waterborne exposure - FF } \\
\hline $3(2.95 \pm 0.10)$ & 1 & $36.9 \pm 0.5^{\mathrm{a}}$ & $1.08 \pm 0.04^{\mathrm{a}}$ & $10.5 \pm 0.7^{a}$ & $29.4 \pm 0.8$ & $55.0 \pm 1.9$ & $20.1 \pm 3.1$ & $20.7 \pm 1.5$ \\
\hline $3(2.85 \pm 0.21)$ & 2 & $39.7 \pm 1.5^{b}$ & $1.30 \pm 0.06^{b}$ & $15.0 \pm 1.5^{b}$ & $33.5 \pm 1.7$ & $53.9 \pm 1.1$ & $21.6 \pm 3.1$ & $19.7 \pm 1.9$ \\
\hline $3(2.99 \pm 0.12)$ & 8 & $35.1 \pm 0.3^{\mathrm{a}}$ & $1.01 \pm 0.06^{\mathrm{a}}$ & $10.5 \pm 0.8^{\mathrm{a}}$ & $32.7 \pm 1.5$ & $55.9 \pm 1.4$ & $19.1 \pm 2.8$ & $21.2 \pm 1.7$ \\
\hline \multicolumn{9}{|c|}{ Series 3: dietary exposure - FR } \\
\hline $1(1.04 \pm 0.10)$ & 2 & $29.7 \pm 0.5^{\mathrm{a}}$ & $0.59 \pm 0.05^{\mathrm{a}}$ & $19.6 \pm 2.6^{\mathrm{a}}$ & $34.3 \pm 5.8$ & $53.5 \pm 2.3$ & $16.2 \pm 4.2$ & $26.4 \pm 2.6^{\mathrm{a}}$ \\
\hline $2.5(2.48 \pm 0.14)$ & 2 & $31.6 \pm 0.8^{a}$ & $0.87 \pm 0.06^{b}$ & $10.4 \pm 1.2^{b}$ & $28.8 \pm 2.2$ & $52.7 \pm 2.4$ & $22.1 \pm 2.7$ & $20.9 \pm 2.1^{b}$ \\
\hline $4(3.82 \pm 0.11)$ & 2 & $36.6 \pm 0.9^{b}$ & $1.14 \pm 0.04^{\mathrm{c}}$ & $10.2 \pm 0.7^{b}$ & $34.0 \pm 1.1$ & $52.6 \pm 2.2$ & $22.9 \pm 3.4$ & $20.2 \pm 2.4^{b}$ \\
\hline \multicolumn{9}{|c|}{ Series 4: dietary exposure - FF } \\
\hline $3(3.11 \pm 0.51)$ & 1 & $34.0 \pm 0.6^{\mathrm{a}}$ & $0.89 \pm 0.05^{\mathrm{ab}}$ & $9.3 \pm 1.1^{\mathrm{a}}$ & $32.9 \pm 2.6$ & $53.8 \pm 0.9$ & $21.2 \pm 0.9^{\mathrm{a}}$ & $21.5 \pm 2.1$ \\
\hline $3(2.98 \pm 0.12)$ & 2 & $36.5 \pm 0.9^{b}$ & $1.21 \pm 0.06^{b}$ & $15.3 \pm 0.3^{\mathrm{b}}$ & $35.0 \pm 1.1$ & $49.9 \pm 3.1$ & $25.1 \pm 3.9^{b}$ & $20.2 \pm 1.2$ \\
\hline $3(3.05 \pm 0.01)$ & 8 & $31.9 \pm 0.5^{\mathrm{a}}$ & $0.74 \pm 0.06^{b}$ & $7.5 \pm 0.4^{\mathrm{a}}$ & $33.2 \pm 1.9$ & $54.0 \pm 2.1$ & $21.2 \pm 4.2^{\mathrm{a}}$ & $22.2 \pm 2.0$ \\
\hline
\end{tabular}


ratios on fish growth and dietary $\mathrm{Cd}$ bioaccumulation. The feeding frequency was at a normal level, i.e. 2 times $\mathrm{d}^{-1}$.

\section{Series 4: dietary Cd exposure-effect of feeding frequency}

To test the effect of feeding frequency on fish growth and dietary $\mathrm{Cd}$ bioaccumulation when the fish are exposed to dietary $\mathrm{Cd}, 3$ levels of feeding frequency were selected (1 [at 9:00 h], 2 [at 9:00 and 15:00 h] and 8 times $\mathrm{d}^{-1}$ [at 0:00, 3:00, 6:00, 9:00 12:00, 15:00, 18:00 and 21:00 h]). The feeding ratio was at a normal level, i.e. $3 \% \mathrm{BW} \mathrm{d}^{-1}$.

\section{Fish feeding and sampling procedures}

The fish in each tank were weighed in bulk at the middle of the feeding experiment to re-adjust feeding ratios. All fish were fed set feed weights at set times using automatic fish feeders (Pet Wang Products). Uneaten food was collected $1 \mathrm{~h}$ after feeding, then dried and re-weighed to calculate the weight of feed ingested by fish. In the waterborne $\mathrm{Cd}$ exposure, the water with $\mathrm{Cd}\left(100 \mu \mathrm{g} \mathrm{l}^{-1}\right)$ added was first artificially renewed with normal seawater before fish were fed; subsequently, fish were provided with a natural diet (Table 1) in seawater without additional $\mathrm{Cd}$. After fish feeding, a $\mathrm{CdCl}_{2}$ solution was added to the seawater to keep the dissolved Cd concentration at $100 \mu \mathrm{g} \mathrm{l}^{-1}$. A water renewal rate of once per hour was maintained in dietary Cd exposure groups by running seawater. The feeding experiment lasted $5 \mathrm{wk}$.

Upon completion of the experiment, all fish were weighed and 3 fish from each tank (6 fish per treatment) were transferred to other aquaria for determination of waterborne $\mathrm{Cd}$ uptake rate and dietary $\mathrm{Cd}$ assimilation efficiency (AE). The remaining fish were deprived of feed for another day and then sacrificed by an overdose of MS-222 (200 $\left.\mu \mathrm{g} \mathrm{l}^{-1}\right)$ for whole body composition analysis and Cd concentration determination in selected tissues (gills, gut, liver, dorsal muscle, carcass [the fish without gills and viscera] and whole body [whole fish]).

\section{Cd uptake rate and assimilation efficiency measurement}

To determine waterborne $\mathrm{Cd}$ uptake rates, 3 fish from each waterborne $\mathrm{Cd}$ exposure tank (6 fish per treatment) were placed in 101 aquaria containing 81 of natural aerated seawater filtered using Whatman glass filters (pore size: $0.22 \mu \mathrm{m}$ ). The water was spiked with $20 \mu \mathrm{g} \mathrm{l} \mathrm{l}^{-1}{ }^{113} \mathrm{Cd}$ (International Atomic Energy Agency Office at USA, New York, in CdO form, and dissolved in $1 \mathrm{~mol} \mathrm{l}^{-1} \mathrm{HNO}_{3}$ to $16.7 \pm 0.6 \mu \mathrm{g}$ $\mathrm{Cd}^{-1}$ ). Since our previous results suggested that juvenile black sea bream take up dissolved Cd linearly with exposure time without saturation over $4 \mathrm{~h}$ (see details in Zhang \& Wang 2006b, 2007b), the fish in the present study were sampled at $4 \mathrm{~h}$ for ${ }^{113} \mathrm{Cd}$ content measurement in fish tissue.

To determine the AE of dietary $\mathrm{Cd}, 4$ fish from each dietary Cd exposure tank (8 fish per treatment) were kept individually in 2.51 aquaria (containing 21 natural aerated seawater) for $3 \mathrm{~d}$ to acclimate to experimental conditions. During those $3 \mathrm{~d}$, the fish were fed at the same feeding ratio/frequency as those in previous experiments. Then, the fish were fed a diet spiked with $10 \mu \mathrm{g} \mathrm{g}^{-1}{ }^{113} \mathrm{Cd}$ (the measured value was $9.8 \pm 0.6 \mu \mathrm{g} \mathrm{g}^{-1}$ ) plus $240 \mu \mathrm{g} \mathrm{g}^{-1}$ natural $\mathrm{Cd}$ (to produce the same concentration as in the long-term dietary exposure) in the next $24 \mathrm{~h}$ using the corresponding feeding ratio or frequency. After feeding with spiked diets, the fish were fed diets containing natural $\mathrm{Cd}$ for $60 \mathrm{~h}$ and then sampled for ${ }^{113} \mathrm{Cd}$ content measurements in fish tissues.

\section{Proximate composition and $\mathrm{Cd}$ content analysis}

All diet and fish tissue samples were dried at $60^{\circ} \mathrm{C}$ for $24 \mathrm{~h}$. The proximate composition analysis of fish and diets were conducted as described by the AOAC (1995). Specifically, dry matter content was determined by oven-drying at $105^{\circ} \mathrm{C}$ to constant weight. Crude ash content was determined by incineration in a muffle furnace $\left(550^{\circ} \mathrm{C}\right.$ for $\left.12 \mathrm{~h}\right)$. Crude protein content $(\mathrm{N} \times 6.25)$ was determined using an Automatic Kjeldahl System (2300 Kjeltec Analyzer Unit, FOSS Tecator). Crude lipid content was determined by ether extraction in a Soxtec System HT6 (Tecator).

Fish tissue and diet samples were ground and then digested using concentrated $\mathrm{HNO}_{3}$ (69\%, ultrapure, Fisher Scientific) for $48 \mathrm{~h}$ at $80^{\circ} \mathrm{C}$. The total $\mathrm{Cd}$ concentrations in water and digested samples were quantified by inductively coupled plasma-mass spectroscopy (ICP-MS, 7700X, Agilent Technologies). The net concentration of ${ }^{113} \mathrm{Cd}\left(\Delta^{113} \mathrm{Cd}\right)$ in the samples with respect to $\mathrm{Cd}$ uptake rate and $\mathrm{AE}$ were determined using the methods described by Croteau et al. (2007). The equations are given in the Appendix. 


\section{Data calculation and statistical analysis}

The parameters regarding growth performance and feed utilization were calculated as follows:

$$
\mathrm{SGR}=100 \times\left(\ln \mathrm{mBW}_{\text {final }}-\ln \mathrm{mBW}_{\text {initial }}\right) / \mathrm{N}
$$

where SGR is specific growth rate $\left(\% \mathrm{~d}^{-1}\right), \mathrm{mBW}_{\text {initial }}$ and $\mathrm{mBW}_{\text {final }}$ are intial and final mean body weight (in $\mathrm{g}$ ), respectively and $\mathrm{N}$ is the number of days;

$\mathrm{FI}_{\mathrm{d}}=100 \times \mathrm{FI}_{\text {total }} /\left[\mathrm{N} \times\left(\mathrm{mBW}_{\text {initial }}+\mathrm{mBW}_{\text {final }}\right) / 2\right]$

where $\mathrm{FI}_{\mathrm{d}}$ is daily feed intake $\left(\% \mathrm{BW} \mathrm{d}^{-1}\right), \mathrm{FI}_{\text {total }}$ is total feed intake (\% BW);

$$
\mathrm{FE}=100 \times \mathrm{DW}_{\text {gain }} / \mathrm{FI}_{\mathrm{d}} \times \mathrm{N}
$$

where FE is feed efficiency (\%), DW $\mathrm{DW}_{\text {gain }}$ is dry weight gain of fish.

The parameters regarding the kinetics of $\mathrm{Cd}$ bioaccumulation were calculated as follows:

$$
J_{\mathrm{w}}=\Delta^{113} \mathrm{Cd} / 4 \mathrm{~h}
$$

where $J_{\mathrm{w}}$ is waterborne $\mathrm{Cd}$ uptake rate $\left(\mathrm{ng} \mathrm{g}^{-1} \mathrm{~h}^{-1}\right)$;

$$
\mathrm{AE}_{\text {diet }}=100 \times \Delta^{113} \mathrm{Cd} \times \mathrm{DW}_{\text {tissue }} /\left(\mathrm{FI}_{\text {total }} \times \mathrm{Cd}_{\text {spike }}\right)
$$

where $\mathrm{AE}_{\text {diet }}$ is the dietary $\mathrm{Cd}$ assimilation efficiency $(\%), \mathrm{DW}_{\text {tissue }}$ is the dry weight of fish tissue, $\mathrm{Cd}_{\text {spike }}$ is the ${ }^{113} \mathrm{Cd}$ concentration in spiked diets;

$$
\begin{aligned}
& \mathrm{RE}=100 \times\left[\mathrm{mBW}_{\text {final }} \times \mathrm{Cd}_{\text {final }}-\mathrm{mBW}_{\text {initial }} \times \mathrm{Cd}_{\text {initial }}\right] / \\
& \left(\mathrm{FI}_{\mathrm{d}} \times \mathrm{N} \times \mathrm{Cd}_{\text {diet }}\right)
\end{aligned}
$$

where $\mathrm{RE}$ is the dietary $\mathrm{Cd}$ retention efficiency (\%), $\mathrm{Cd}_{\text {initial }}$ and $\mathrm{Cd}_{\text {final }}$ are the initial and final $\mathrm{Cd}$ concentration in fish, respectively, and $\mathrm{Cd}_{\text {diet }}$ is the $\mathrm{Cd}$ concentration in the diet.
The data were analyzed by 1-way analysis of variance (ANOVA) followed by Tukey's HSD (honestly significant difference) post hoc test for multiple comparisons between different treatments (Table 2). The only exception is that the differences between 2 and $4 \% \mathrm{BW} \mathrm{d}^{-1}$ fish in waterborne $\mathrm{Cd}$ exposure groups were determined by $t$-test since there were only 2 groups. Normality and homogeneity of data were determined using a 1-sample Kolmogorov-Smirnov test and Levene's test. The data were $\log (x+1)$ transformed if normality and homogeneity were not assumed. The difference was regarded as significant when $\mathrm{p}<0.05$. All statistical analyses were performed with the SPSS 18.0 software package.

\section{RESULTS}

\section{Waterborne Cd exposure-effects of feeding ratio}

The juvenile black sea bream in the control groups showed normal growth performance (SGR: $1.55 \pm$ $0.08 \% \mathrm{~d}^{-1}$; mean $\pm \mathrm{SD}$ ), suggesting that the present feeding experiment was conducted in a well-regulated culture condition. In the control groups, the $\mathrm{Cd}$ concentration was low $\left(0.17 \pm 0.23 \mu \mathrm{g} \mathrm{g}^{-1}\right.$; mean $\left.\pm \mathrm{SD}\right)$.

When the fish were exposed to waterborne $\mathrm{Cd}$ exposure, the group without feeding $\left(0 \% \mathrm{BW} \mathrm{d}^{-1}\right)$ showed the lowest and even negative SGR (Table 2). The fish fed $4 \% \mathrm{BW} \mathrm{d}^{-1}$ grew fastest. The FE of the fish fed $2 \% \mathrm{BW} \mathrm{d}^{-1}$ was significantly higher than that of the fish fed $4 \% \mathrm{BW} \mathrm{d}^{-1}$. The group without feeding displayed the lowest crude lipid content (CL) but the highest ash content in whole body samples (Table 2).

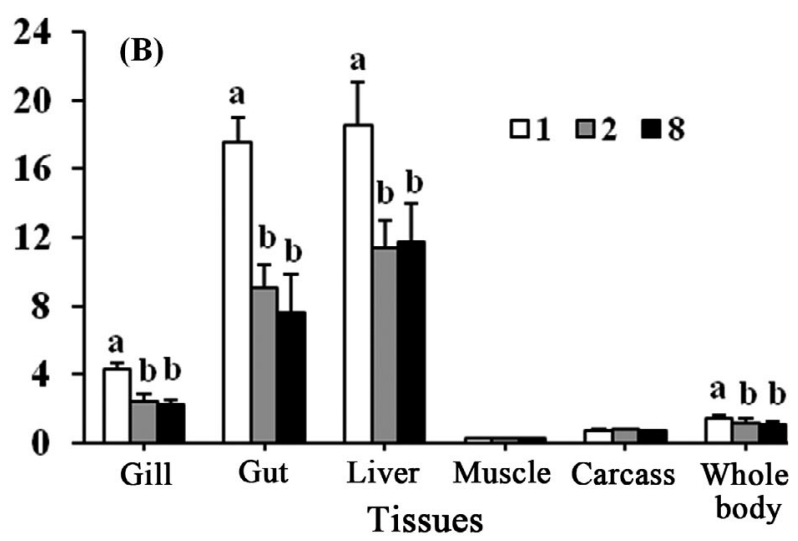

Fig. 1. Cadmium concentration ( $\mu \mathrm{g} \mathrm{Cd} \mathrm{g}^{-1}$ in dry matter) in the gills, gut, liver, muscle, carcass and whole body of black sea bream Acanthopagrus schlegeli exposed to waterborne Cd $\left(97.2 \mu \mathrm{g} \mathrm{l}^{-1}\right)$ for $5 \mathrm{wk}$ at 3 different levels of feeding ratio (FR) or frequency (FF). (A) FR treatment: fish were fed 0, 2 and $4 \%$ body weight $d^{-1}$ at 2 times $d^{-1}$. (B) FF treatment: fish were fed 1, 2 and 8 times $\mathrm{d}^{-1}$ at a feeding ratio of $3 \%$ body weight $\mathrm{d}^{-1}$. Mean $\pm \mathrm{SD}, \mathrm{n}=6$ ( 3 fish per replicate tank); means of the same tissue with different superscripts are significantly different among treatments $(p<0.05)$ 

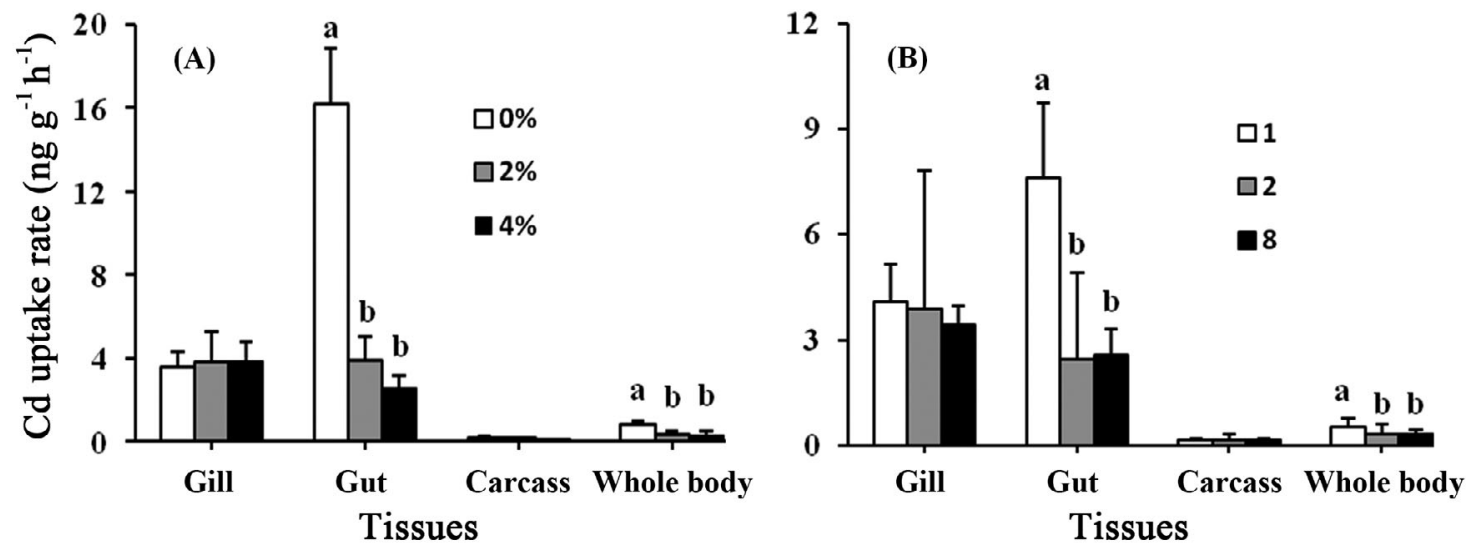

Fig. 2. Uptake rate $\left(\mathrm{ng} \mathrm{g}^{-1} \mathrm{~h}^{-1}\right)$ of waterborne $\mathrm{Cd}$ in various tissues of black sea bream Acanthopagrus schlegeli at 3 different feeding ratios or frequencies. Experimental treatments and statistical significance as in Fig. 1

The fish without feeding had the highest $\mathrm{Cd}$ concentrations in their gut $\left(22.8 \mu \mathrm{g} \mathrm{g}^{-1}\right)$, and also accumulated significantly higher $\mathrm{Cd}$ concentration in the muscle, carcass and whole body (Fig. 1A). The uptake rate of waterborne $\mathrm{Cd}$ was also highest in non-fed fish (Fig. 2A). The waterborne Cd uptake rate in gut was about 6 -fold higher than that in the gills when the fish was not feeding, whereas those 2 organs showed a similar $\mathrm{Cd}$ uptake rate in fish fed 2 or $4 \% \mathrm{BW} \mathrm{d}^{-1}$ (Fig. 2A). Moreover, the fish without feeding showed a higher percentage of $\mathrm{Cd}$ in their gut $(31.5 \%)$, but lower values in their gills $(4.9 \%)$ and liver $(10.6 \%)$ than other groups (Fig. 3A).

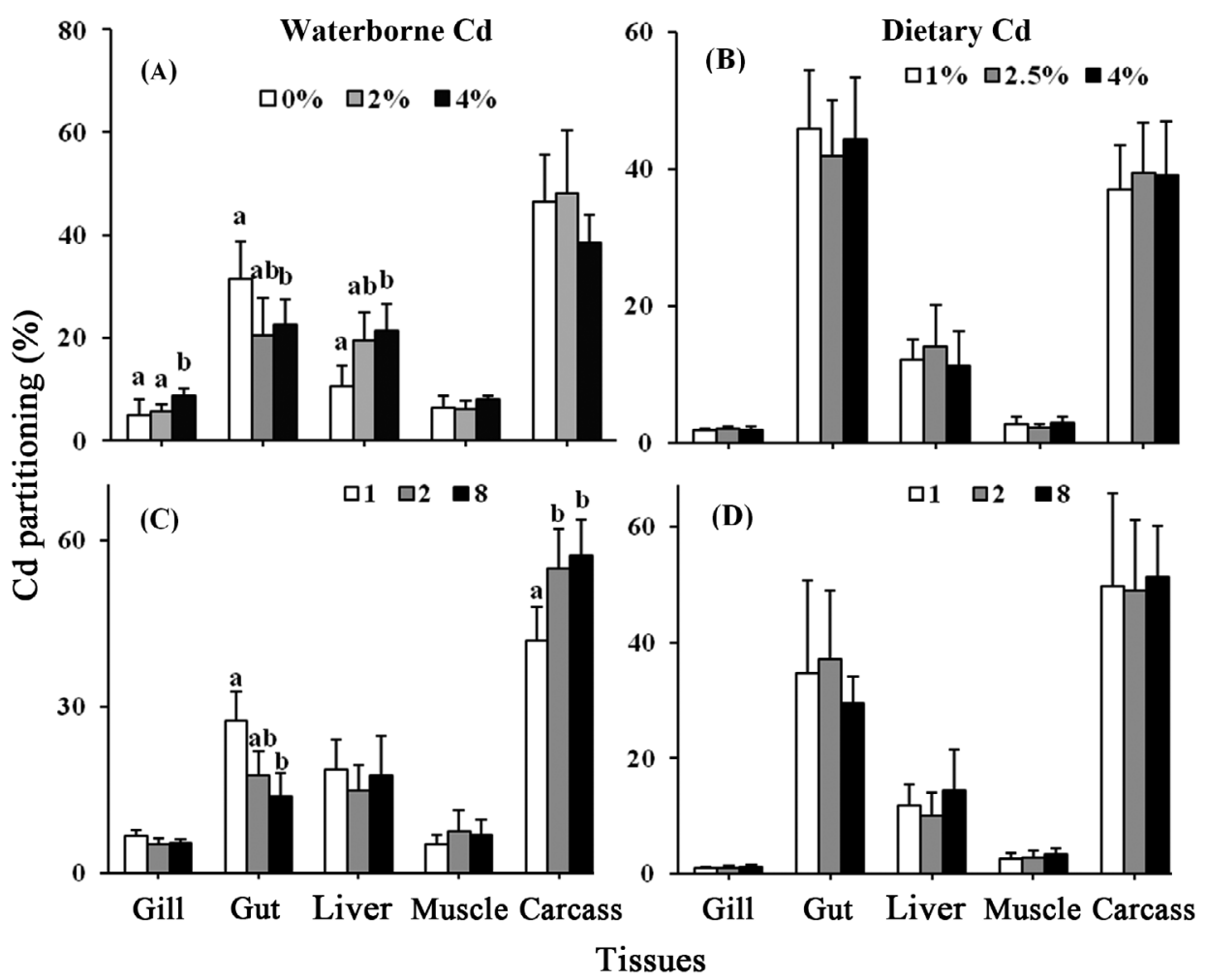

Fig. 3. Cadmium partitioning (\%) among the gills, gut, liver, muscle and carcass of black sea bream Acanthopagrus schlegeli under 5 wk exposure of waterborne or dietary $\mathrm{Cd}$ at 3 different levels of feeding ratio (FR) or frequency (FF). FR treatments: fish were fed (A) 0,2 and $4 \%$ body weight (BW) $\mathrm{d}^{-1}$ under waterborne exposure or (B) $1,2.5$ and $4 \%$ BW $\mathrm{d}^{-1}$ under dietary exposure. FF was 2 times d ${ }^{-1}$. FF treatments: fish were fed 1, 2 and 8 times $d^{-1}$ at a FR of $3 \% \mathrm{BW} \mathrm{d}^{-1}$ under (C) waterborne or (D) dietary exposure. Mean $\pm \mathrm{SD}, \mathrm{n}=6$ (3 fish per replicate tank); means of the same tissue with different superscripts are significantly different among treatments $(\mathrm{p}<0.05)$ 


\section{Waterborne Cd exposure-effects of feeding frequency}

Under waterborne Cd exposure, the SGR and FE were highest when fish were fed 2 times $\mathrm{d}^{-1}$ (Table 2), but there was no significant difference in fish body composition between the groups with different feeding frequencies.

The Cd concentration was significantly higher in the gills, gut, liver and whole body when fish were fed 1 time $\mathrm{d}^{-1}$ compared with those fed 2 or 8 times $\mathrm{d}^{-1}$ (Fig. 1B). The fish fed 1 time $\mathrm{d}^{-1}$ took up waterborne $\mathrm{Cd}$ in the gut (7.6 ng g ${ }^{-1} \mathrm{~h}^{-1}$ ) approximately 3-fold faster than those fed $2\left(2.4 \mathrm{ng} \mathrm{g}^{-1} \mathrm{~h}^{-1}\right)$ or 8 times $\mathrm{d}^{-1}(2.6 \mathrm{ng}$ $\mathrm{g}^{-1} \mathrm{~h}^{-1}$ ) (Fig. 2B). Moreover, the Cd uptake rates in the gut of fish fed 1 time $^{-1}$ were clearly higher than those in the gills ( $\left.4.1 \mathrm{ng} \mathrm{g}^{-1} \mathrm{~h}^{-1}\right)$, but the guts of fish fed 2 and 8 times $\mathrm{d}^{-1}$ showed an even slightly lower Cd uptake rate than did the gills (Fig. 2B). Additionally, the proportions of $\mathrm{Cd}$ in gut decreased steadily when the feeding frequency increased (Fig. 3C).

\section{Dietary Cd exposure-effects of feeding ratio}

In dietary $\mathrm{Cd}$ exposure groups, the SGR of fish steadily increased with the increasing feeding ratios. The group with $1 \% \mathrm{BW} \mathrm{d}^{-1}$ exhibited a significantly higher FE and ash content than the others (Table 2).

The fish fed $4 \% \mathrm{BW} \mathrm{d}^{-1}$ showed the lowest dietary $\mathrm{Cd} \mathrm{AE}(3.8 \%)$, while $\mathrm{AE}$ values were similar between the other 2 groups $(6.1$ and $6.6 \%$ in fish fed 1 and
$2.5 \% \mathrm{BW} \mathrm{d}^{-1}$, respectively). After $5 \mathrm{wk}$ of dietary $\mathrm{Cd}$ exposure, the fish fed $1 \% \mathrm{BW} \mathrm{d}{ }^{-1}$ accumulated the least $\mathrm{Cd}$ in all body parts, and the fish fed 2 and $4 \%$ BW d ${ }^{-1}$ accumulated comparable Cd (Fig. 4A). Moreover, the gut and carcass accounted for most of the Cd body burden $(>80 \%)$, but the proportions of $\mathrm{Cd}$ partitioned into different tissues were similar between different feeding ratios (Fig. 3B).

\section{Dietary Cd exposure-effects of feeding frequency}

When the fish were exposed to dietary $\mathrm{Cd}$ at different feeding frequencies, the SGR, FE and CL were highest in the fish fed 2 times $\mathrm{d}^{-1}$ (Table 2).

The AE in fish fed 2 times $\mathrm{d}^{-1}(6.0 \%)$ was about 2 fold that of the other 2 groups (3.2 and $3.5 \%$ in fish fed 1 and 8 times $d^{-1}$, respectively). At the end of $5 \mathrm{wk}$ of dietary $\mathrm{Cd}$ exposure, the fish fed 1 time $\mathrm{d}^{-1}$ accumulated significantly lower $\mathrm{Cd}$ contents in all body parts except the gills, and those fed 2 times $\mathrm{d}^{-1}$

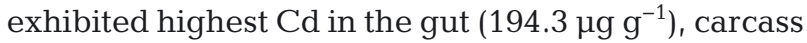
$\left(7.5 \mathrm{\mu g} \mathrm{g}^{-1}\right)$ and whole body (11.5 $\mathrm{\mu g} \mathrm{g}^{-1}$; Fig. 4B), whereas feeding frequency did not significantly impact the Cd partitioning among tissues (Fig. 3D).

Moreover, when the fish were exposed to dietary $\mathrm{Cd}$ at different feeding ratios or feeding frequencies, dietary CRE (\%) was significantly lower at higher feeding ratios (Fig. 5A), and was highest in the fish fed twice daily, compared to 1 and 8 times $\mathrm{d}^{-1}$ (Fig. 5B). CRE was positively related to FE (\%), across all ratios and frequencies tested (Fig. 5C).
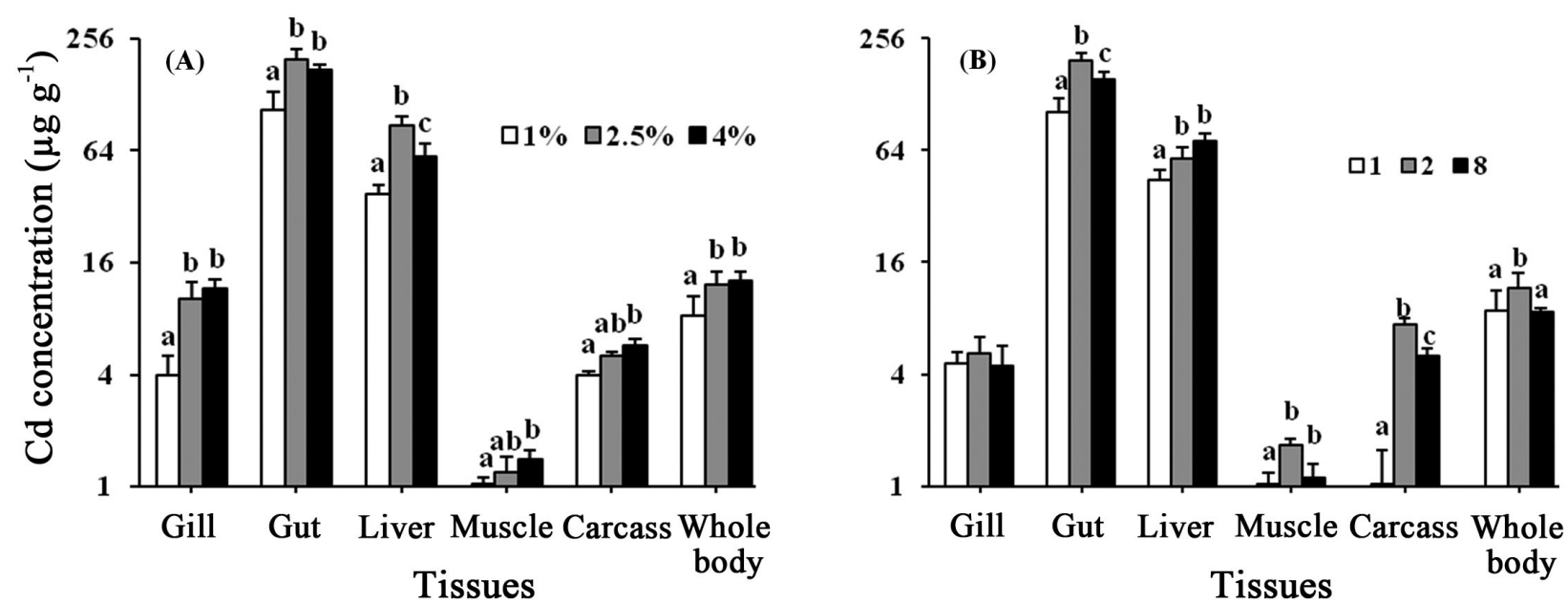

Fig. 4. Cadmium concentration ( $\mu \mathrm{g} \mathrm{Cd} \mathrm{g}^{-1}$ in dry matter) in the gills, gut, liver, muscle, carcass and whole body of black sea bream Acanthopagrus schlegeli exposed to dietary Cd $\left(254.4 \mathrm{\mu g} \mathrm{g}^{-1}\right)$ for $5 \mathrm{wk}$ at 3 different levels of feeding ratio (FR) or frequency (FF). (A) FR treatment: fish were fed 1, 2.5 and $4 \%$ body weight $\mathrm{d}^{-1}$ at a FF of 2 times $\mathrm{d}^{-1}$. (B) FF treatment: fish were fed 1, 2 and 8 times $d^{-1}$ at a FR of $3 \%$ body weight $d^{-1}$. Mean $\pm S D, n=6$ (3 fish per replicate tank); means of the same tissue with different superscripts are significantly different among treatments $(p<0.05)$. Note: quadratic scale of $y$-axis 

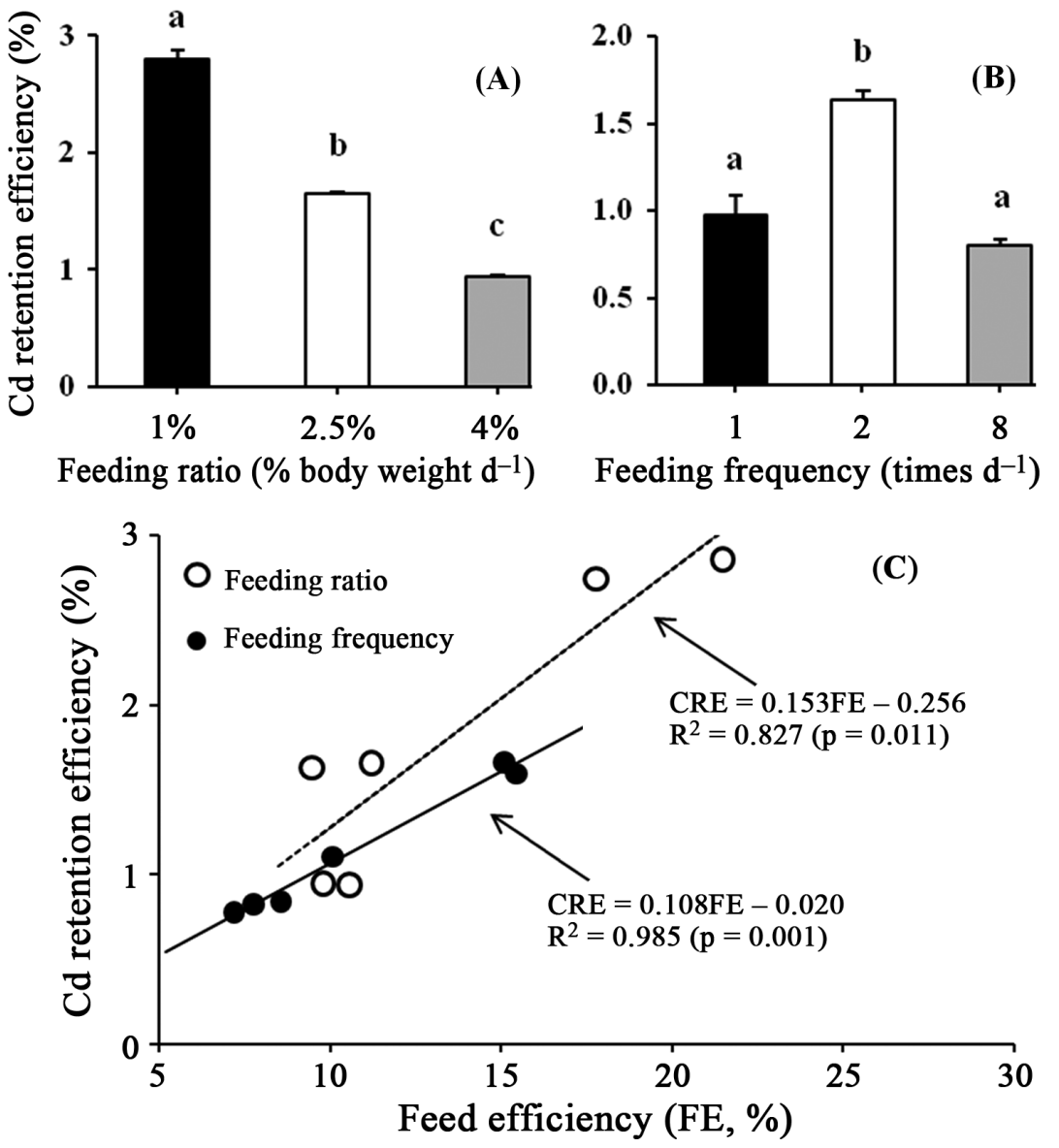

Fig. 5. (A,B) Cadmium retention efficiency (CRE, \%) and $(\mathrm{C})$ correlation between feed efficiency (FE, \%) and CRE in black sea bream Acanthopagrus schlegeli exposed to dietary $\mathrm{Cd}\left(254.4 \mathrm{\mu g} \mathrm{g}^{-1}\right)$ for $5 \mathrm{wk}$ at different feeding ratios (FR) or frequencies (FF). (A) CRE of fish fed at 3 different FR of 1, 2.5 and $4 \%$ body weight $\mathrm{d}^{-1}$ at a FF of 2 times $\mathrm{d}^{-1}$. (B) CRE of fish fed at 3 different FF of 1, 2 and 8 times $d^{-1}$ with a FR of $3 \%$ body weight $d^{-1}$. Means $( \pm$ SD), $n=6$ ( 3 fish per replicate tank) in $(\mathrm{A}, \mathrm{B})$; different superscripts indicate significantly different treatments $(\mathrm{p}<0.05)$. Values in $(\mathrm{C})$ are means $(\mathrm{n}=3$ fish $)$ per replicate tank

served protection by feeding against metal accumulation is that the ingestion, digestion and assimilation of food prevents the uptake of waterborne metals in the gastrointestinal tract by decreasing the drinking of water (Wood et al. 2010) and/or changing the physico-chemical environment of the intestines (e.g. $\mathrm{pH}$ and acid-base disturbances [Taylor et al. 2007, Bucking et al. 2009], gut fluid volume [Wood et al. 2010], bulk ion exchange and ion concentration [Bucking et al. 2011]). Alternatively, it is noteworthy that the fish in all these studies (including the present study) were fasted for $>10 \mathrm{~d}$, which usually resulted in an insufficient intake of essential nutrients, thus resulting in potential disturbances in normal physiological processes/functions, such as energy metabolism and partitioning (Sun et al. 2003), osmoregulation (e.g. $\mathrm{Na}^{+}$regulation), metal detoxication (e.g. metallothionein synthesis; Hashemi et al. 2007, 2008) and homeostatic regulation of trace metals (e.g. biliary discharge of Ag; Wood et al. 2010). All these physiological alterations are likely to be the causes of increasing metal bioaccumulation in the fish when they were fasted.

Furthermore, this study is the first one to report that feeding frequency could significantly affect waterborne $\mathrm{Cd}$ bioaccumulation in fish. The fish

\section{DISCUSSION}

\section{Starvation and waterborne Cd bioaccumulation}

In the present study, the fish starved showed significantly higher waterborne $\mathrm{Cd}$ accumulation and uptake rates compared with those fed diets, notably in the gut. Consistently, Wood et al. (2010) observed the same phenomenon in marine gulf toadfish $(\mathrm{Op}$ sanus beta) when it was exposed to waterborne Ag for $22 \mathrm{~d}$. Their results indicated that the net whole body accumulation of Ag was reduced by $>50 \%$ in fish fed daily to satiation compared with those fasted. In freshwater common carp (Cyprinus carpio), similar results were obtained (Hashemi et al. 2007, 2008). Here, the most obvious interpretation for the ob- fed once per day showed the highest Cd body burden and $\mathrm{Cd}$ uptake rates in the gut. This finding can probably be attributed to the occurrence of empty guts between the feeding intervals when no food is ingested after gastric evacuation, with gastric evacuation times being strongly correlated with feeding intervals (Lee et al. 2000, Riche et al. 2004). In tilapia (Oreochromis niloticus), for instance, the stomachs of fish fed 5 times $\mathrm{d}^{-1}$ still contained some of the food at $24 \mathrm{~h}$, whereas stomachs were empty and flaccid in fish fed 3 times $d^{-1}$ (Riche et al. 2004). Thus, in the present study, the gastrointestinal tract of the fish fed once a day was probably empty for a much longer time compared to those fed 2 or 8 times $\mathrm{d}^{-1}$. If fish guts are empty, with no further food ingestion during feeding intervals, the fish may be 
temporarily starved and thus increase the Cd uptake, as discussed above.

\section{Feeding ratio and frequency affecting dietary $\mathrm{Cd}$ bioaccumulation}

Dietary Cd assimilation efficiency (AE) ranged from 3.2 to $6.6 \%$ when fish were fed with artificial diets in this study, which agreed well with the values in the study by Zhang \& Wang (2005) (4.2 to 6.2\%). Both feeding ratio and feeding frequency had significant effects on fish $\mathrm{Cd}$ body burden and AE. The ingestion rate (IR, equivalent to $F R$ in the present study) and gut passage time (GPT) are suggested to be the 2 most important factors determining the AEs of metals in many aquatic organisms (e.g. Zhang \& Wang 2006a, Croteau et al. 2007). In most cases, the AEs of metals increased with prolonged GPT, and AEs were higher at a lower IR and vice versa (Zhang \& Wang 2006a, Croteau et al. 2007). In our study, the higher AEs at a lower FR probably resulted from the greater efficiency of the limited number of transporters on the intestine epithelium and/or enhanced $\mathrm{Cd}$ digestion due to the numerous digestive enzyme contacts and reactions (Zhang \& Wang 2006a). Similarly, black sea bream fed 2 times $\mathrm{d}^{-1}$ showed higher Cd AEs than those fed 1 or 8 times $d^{-1}$ when FR was fixed at $3 \% \mathrm{BW} \mathrm{d}^{-1}$. A somewhat more complex digestive process was noted with regard to changes in IR and GPT. The low Cd AEs in fish fed 1 time $\mathrm{d}^{-1}$ might be the main factor attributing to the high IR for each meal (i.e. when the diets of $3 \% \mathrm{BW} \mathrm{d}^{-1}$ were divided to 2 or 8 times $\mathrm{d}^{-1}$, the IR is lower for each meal compared with the diets fed once a day). However, when the $3 \%$ BW diet was divided to allow feeding 8 times $\mathrm{d}^{-1}$, i.e. a feeding interval of only $3 \mathrm{~h}$, fish may have experienced gastric overload (Riche et al. 2004). Thus, the GPT of each meal was very short, possibly leading to inadequate digestion of food and thus low AEs of Cd (Zhang \& Wang 2006a).

In our study, when exposed to waterborne $\mathrm{Cd}$, the fish undergoing starvation showed $\mathrm{Cd}$ values of $0.14 \mu^{-1} \mathrm{~g}^{-1}$ muscle wet weight (WW), which exceeded the permissible level of $0.1 \mu \mathrm{g} \mathrm{g}^{-1}$ according to China's national standard (China National Standards Management Department 2001) and that of the European Union (2001). When the black sea bream were exposed to dietary $\mathrm{Cd}$, only those fed once a day showed the lowest $\mathrm{Cd}$ content of $0.083 \mu \mathrm{g} \mathrm{g}^{-1}$ WW; the Cd contents in the other groups were higher than the permissible level of $0.1 \mu^{-1} \mathrm{~g}^{-1}$ (i.e. 0.23 to $\left.0.58 \mu \mathrm{g} \mathrm{g}^{-1} \mathrm{WW}\right)$.

\section{Suitable feeding ratio and frequency for fish growth performance}

When exposed to waterborne or dietary $\mathrm{Cd}$ for $5 \mathrm{wk}$, the growth and feed utilization of the black sea bream was often lower than that detected in similar studies on black sea bream (Sun et al. 2003, Lou et al. 2006, 2007, Zhang et al. 2012), suggesting the potentially toxic effects of waterborne and dietary $\mathrm{Cd}$ to fish. The fish showed the best growth performance when fed at $4 \% \mathrm{BW} \mathrm{d}^{-1}$ twice a day, which was consistent with those previous studies. For instance, Lou et al. (2007) found that the SGR of fish were highest at $3 \% \mathrm{BW} \mathrm{d}^{-1}$ and then decreased slightly when the feeding ratio reached $4 \% \mathrm{BW} \mathrm{d}^{-1}$. Additionally, we found the same effect of feeding frequency on SGR and FE as in Lou et al. (2007), i.e. the optimal feeding frequency was 2 times $\mathrm{d}^{-1}$ and high feeding frequency (6 times or 8 times $\mathrm{d}^{-1}$ ) led to reductions in growth rate and feed utilization, regardless of $\mathrm{Cd}$ exposure.

\section{Implication for feeding management in marine fish farming}

Estuarine and coastal areas are the main regions of marine aquaculture and, concurrently, are the ultimate receptacles of the bulk of anthropogenic pollutants; specifically, they are often subjected to Cd pollution (e.g. Cheung et al. 2008, Pan \& Wang 2012). Furthermore, the $\mathrm{Cd}$ pollution of the environment may result in increased $\mathrm{Cd}$ bioaccumulation in some kinds of feed ingredients (e.g. Mai et al. 2006, Dang \& Wang 2009). Thus, marine fish farming is likely to be subjected to $\mathrm{Cd}$ pollution, occasionally via a dissolved or dietary route.

The feeding frequency and feeding ratio in realistic management protocols often vary greatly with seasons, feeding strategies and the marketable demands of targeted fish. For instance, feed restrictionrefeeding cycles are widely used in aquaculture to induce compensatory growth in numerous fish species as a way of increasing profits and reducing waste load to the environment (Ali et al. 2003, Sevgili et al. 2012). The present study suggested that starvation or a decrease in feeding frequency may substantially increase the risk of excessive metal accumulation in farmed fish, if feed or water are contaminated by trace metals. Therefore, in Cd-contaminated seawater environments (fish feeds are free of cadmium contamination), feeding frequency is recommended to be 2 times $\mathrm{d}^{-1}$ and feeding ratio to be 3 to $4 \%$ 
BW $\mathrm{d}^{-1}$ for juvenile black sea bream, from a product safety and cost-efficiency perspective.

Furthermore, this study found that feeding ratio and frequency were vital factors influencing dietary $\mathrm{Cd}$ bioaccumulation. The digestion and assimilation of non-essential metals probably coincides with the assimilation of essential nutrients. It is well recognized that feed efficiency should be kept as high as possible to promote cost-efficiency in commercial fish farming. Therefore, it appears difficult to decrease dietary metal bioaccumulation via the management of feeding ratio and frequency without imposing a negative effect on feed efficiency and fish growth performance. Moreover, it is widely acknowledged that diet is the predominant route of metal exposure for most aquatic organisms (Rainbow 2007, Wang et al. 2012). Thus, the best way to prevent dietary metal bioaccumulation is to decrease metal contents in fish diets.

In summary, our findings clearly demonstrated that feeding ratio and feeding frequency were important factors affecting $\mathrm{Cd}$ bioaccumulation in juvenile black sea bream. Fasting or feeding less frequently may expose fish to higher risks of waterborne $\mathrm{Cd}$ contamination, due to an increase in waterborne $\mathrm{Cd}$ uptake through the gastrointestinal tract. Changing feeding ratios and frequencies can also affect dietary $\mathrm{Cd}$ accumulation in fish. However, it may not be a practical way to reduce dietary $\mathrm{Cd}$ contamination, since it affects $\mathrm{Cd}$ assimilation and nutrient utilization in parallel. As the predominant source of $\mathrm{Cd}$ bioaccumulation in fish is their diet, it is important to control the Cd contents in feed.

Acknowledgements. We are extremely grateful to Dr. Geng Qin for technical assistance in feeding experiments. This research was financially supported by the Chinese Academy of Sciences Strategic Pilot Project (XDA11020204), the National Natural Science Foundation of China (41376161) and the 100 Talents Program of the Chinese Academy of Sciences to L.Z., as well as the Natural Science Funds of South China Sea Institute of Oceanology for Young Scholars (SQ201217) and the National Science Foundation of Guangdong Province (S2013010012510) to W.Z.

\section{LITERATURE CITED}

Ali M, Nicienza A, Wootton RJ (2003) Compensatory growth in fishes: a response to growth depression. Fish Fish 4: $147-190$

AOAC (Association of Official Analytical Chemists) (1995) Official method analysis, 16th edn. Association of Official Analytical Chemists, Arlington, VA

Bucking C, Fitzpatrick JL, Nadella SR, Wood CM (2009) Postprandial metabolic alkalosis in the seawater-acclimated trout: the alkaline tide comes in. J Exp Biol 212:2159-2166
Bucking C, Fitzpatrick JL, Nadella SR, McGaw I, Wood CM (2011) Assimilation of water and dietary ions by the gastrointestinal tract during digestion in seawater-acclimated rainbow trout. J Comp Physiol B 181:615-630

Cheung KC, Leung HM, Wong MH (2008) Metal concentrations of common freshwater and marine fish from the Pearl River delta, South China. Arch Environ Contam Toxicol 54:705-715

China National Standards Management Department (2001) Safety qualification for agricultural product for non-environmental pollution aquatic products. GB 18406.4-2001, China National Standards Management Department, Beijing

> Croteau MN, Luoma SN, Pellet B (2007) Determining metal assimilation efficiency in aquatic invertebrates using enriched stable metal isotope tracers. Aquat Toxicol 83: 116-125

Dang F, Wang WX (2009) Assessment of tissue-specific accumulation and effects of cadmium in a marine fish fed contaminated commercially produced diet. Aquat Toxicol 95:248-255

European Union (2001) Commission regulation as regards heavy metals. Directive 2001/22/EC, No. 466/2001, the European Community, Brussels

FAO (Food and Agriculture Organization of the United Nations) (2012) Status and trends. Overview. In: Part I: world review of fisheries and aquaculture. The state of world fisheries and aquaculture. FAO, Rome, p 3-18. Available at www.fao.org/docrep/016/i2727e/i2727e00. htm

Gonzalez EB, Umino T, Nagasawa K (2008) Stock enhancement programe for black sea bream, Acanthopagrus schlegeli (Bleeker), in Hiroshima Bay, Japan: a review. Aquacult Res 39:1307-1315

Grosell M (2006) Intestinal anion exchange in marine fish osmoregulation. J Exp Biol 209:2813-2827

> Hashemi S, Blust R, De Boeck G (2007) The effect of food rations on the tissue specific copper accumulation patterns of sublethal waterborne exposure in Cyprinus carpio. Environ Toxicol Chem 26:1507-1511

- Hashemi S, Blust R, Boeck GD (2008) The effect of starving and feeding on copper toxicity and uptake in $\mathrm{Cu}$ acclimated and non-acclimated carp. Aquat Toxicol 86:142-147

Lee S, Hwang U, Cho SH (2000) Effects of feeding frequency and dietary moisture content on growth body composition and gastric evacuation of juvenile Korean rockfish (Sebastes schlegeli). Aquaculture 187:399-409

Lou B, Mao GM, Luo J, Xin J, Chen XC, Shi HD (2006) Effects of feeding frequency on growth and body biochemical composition of Sparus macrocephalus. Mar Fish Res 27:19-24 (in Chinese with English abstract)

Lou B, Mao GM, Luo J, Xin J, Chen XC, Shi HD (2007) Effects of feeding rate on growth and body biochemical composition of Sparus macrocephalus. J Shanghai Fish Univ 16:230-235 (in Chinese with English abstract)

- Luo XS, Yu S, Zhu YG, Li XD (2012) Trace metal contamination in urban soils of China. Sci Total Environ 421-422: $17-30$

Mai KS, Li HT, Ai QH, Duan QY and others (2006) Effects of dietary squid viscera meal on growth and cadmium accumulation in tissues of Japanese seabass, Lateolabrax japonicas (Cuvier 1828). Aquacult Res 37:1063-1069

Pan K, Wang WX (2012) Trace metal contamination in estuarine and coastal environments in China. Sci Total Environ 421-422:3-16 
Rainbow PS (2007) Trace metal bioaccumulation: models, metabolic availability and toxicity. Environ Int 33:576-582

Riche M, Haley DI, Oetker M, Garbrecht S, Garling DL (2004) Effect of feeding frequency on gastric evacuation and the return of appetite in tilapia Oreochromis niloticus (L). Aquaculture 234:657-673

Sevgili H, Hossu B, Emre Y, Kanyilmaz M (2012) Compensatory growth after various levels of dietary protein restriction in rainbow trout, Oncorhynchus mykiss. Aquaculture 344-349:126-134

Sun Y, Zheng B, Zhang B, Tang QS (2003) Effects of ration level and food species on energy budget of Sparus macrocephalus. Mar Fish Res 23:5-10

Taylor JR, Whittamore JM, Wilson RW, Grosell M (2007) Postprandial acid-base balance and ion regulation in freshwater and seawater-acclimated European flounder, Platichthys flesus. J Comp Physiol B 177:597-608

Wang WX, Wong RSK (2003) Combined effects of food quantity and quality on $\mathrm{Cd}, \mathrm{Cr}$ and $\mathrm{Zn}$ assimilation to the green mussels, Perna viridis. J Exp Mar Biol Ecol 290: 49-69

> Wang WX, Onsanit S, Dang F (2012) Dietary bioavailability of cadmium, inorganic mercury, and zinc to a marine fish: effects of food composition and type. Aquaculture 356/357:98-104

Wei B, Yang L (2010) A review of heavy metal contaminations in urban soils, urban road dusts and agricultural soils from China. Microchem J 94:99-107

Wood CM, Grosell M, McDonald MD, Playle RC, Walshb PJ (2010) Effects of waterborne silver in a marine teleost, the gulf toadfish (Opsanus beta): effects of feeding and chronic exposure on bioaccumulation and physiological responses. Aquat Toxicol 99:138-148
Wu CF, Liu H, Qin LX, Luo BZ, Fang YM, Yuan WJ, Cai H (2013) Probability assessment of cadmium exposure level from aquatic food in Shanghai residents. J Environ Occup Med 2:89-97 (in Chinese with English abstract)

Yu S, Sheng XH, Tang J, Yu C, Ying Y, Li HT (2006) Contents of cadmium and lead of selected food products in Zhengjiang Province, China. Chinese J Health Lab Technol 16:328-329 (in Chinese with English abstract)

Zhang L, Wang WX (2005) Effects of Zn pre-exposure on Cd and $\mathrm{Zn}$ bioaccumulation and metallothionein levels in two species of fish. Aquat Toxicol 73:353-369

Zhang L, Wang WX (2006a) Significance of subcellular metal distribution in prey in influencing the trophic transfer of metals in a marine fish. Limnol Oceanogr 51:2008-2017

Zhang L, Wang WX (2006b) Alteration of dissolved cadmium and zinc uptake kinetics by metal pre-exposure in the black sea bream (Acanthopagrus schlegeli). Environ Toxicol Chem 25:1312-1321

Zhang L, Wang WX (2007a) Gastrointestinal uptake of cadmium and zinc by a marine teleost Acanthopagrus schlegeli. Aquat Toxicol 85:143-153

Zhang L, Wang WX (2007b) Waterborne cadmium and zinc uptake in a euryhaline teleost Acanthopagrus schlegeli acclimated to different salinities. Aquat Toxicol 84:173-181

Zhang L, Wang WX (2007c) Size-dependence of the potential for metal biomagnification in early life stages of marine fish. Environ Toxicol Chem 26:787-794

> Zhang Y, Øverland M, Xie S, Zhiyong Dong, Zhenming Lv, Junzhuo Xu, Trond Storebakken (2012) Mixtures of lupin and pea protein concentrates can efficiently replace high-quality fish meal in extruded diets for juvenile black sea bream (Acanthopagrus schlegeli). Aquaculture 354/355:68-74

Appendix. Equations used to calculate the relative amount of ${ }^{113} \mathrm{Cd}$ in the standards $\left(\mathrm{p}^{113}\right.$, the standard solution used in ICP-MS analysis), the concentrations of ${ }^{113} \mathrm{Cd}$ in the experimental samples $\left(\mathrm{p}_{\mathrm{e}}{ }^{113}\right)$, the original concentration of ${ }^{113} \mathrm{Cd}$ in each sample in the absence of a spike $\left(\mathrm{p}_{\mathrm{o}}{ }^{113}\right)$ and the net concentration increase in ${ }^{113} \mathrm{Cd}\left(\Delta^{113} \mathrm{Cd}\right)$ in each sample

\begin{tabular}{|ll|}
\hline & Equations \\
\hline $\mathrm{p}^{113}$ & Signal intensity ${ }^{113} \mathrm{Cd} /$ signal intensity $\left({ }^{106} \mathrm{Cd}+{ }^{108} \mathrm{Cd}+{ }^{110} \mathrm{Cd}+{ }^{111} \mathrm{Cd}+{ }^{112} \mathrm{Cd}+{ }^{113} \mathrm{Cd}+{ }^{114} \mathrm{Cd}\right)$ \\
$\mathrm{p}_{\mathrm{e}}{ }^{113}$ & $\mathrm{p}^{113} \times \mathrm{T}^{113} \mathrm{Cd}\left(\mathrm{T}^{113} \mathrm{Cd}\right.$ was the total Cd concentration inferred from ${ }^{113} \mathrm{Cd}$ signal intensity $)$ \\
$\mathrm{p}_{\mathrm{o}}{ }^{113}$ & $\mathrm{p}^{113} \times \mathrm{T}^{114} \mathrm{Cd}\left(\mathrm{T}^{114} \mathrm{Cd}\right.$ was the total Cd concentration inferred from ${ }^{114} \mathrm{Cd}$ signal intensity) \\
$\Delta^{113} \mathrm{Cd}$ & $\mathrm{p}_{\mathrm{e}}{ }^{113}-\mathrm{p}_{\mathrm{o}}{ }^{113}$ \\
\hline
\end{tabular}

Editorial responsibility: Megan La Peyre, Baton Rouge, Louisiana, USA
Submitted: December 15, 2014; Accepted: June 30, 2015

Proofs received from author(s): September 8, 2015 